\title{
PRIORITIZATION OF SUSTAINABLE WATER MANAGEMENT STRATEGIES IN ARID AND SEMI-ARID REGIONS USING SWOT COUPLED AHP TECHNIQUE IN ADDRESSING SDGs
}

\author{
Mohammad Ebrahim Banihabib ${ }^{1 \bowtie}$, Arash Noori ${ }^{1}$, Luboš Jurík², Igor Gacko², Nargis Mirzaie ${ }^{1}$ \\ ${ }^{1}$ Department of Irrigation and Drainage, College of Aburaihan, University of Tehran, Emam Reza Blvd., Pakdasht, Tehran, Iran \\ 2 Department of Water Resources and Environmental Engineering (DWREE), The Slovak University of Agriculture in Nitra, \\ Hospodárska 7, Nitra, Slovakia
}

\begin{abstract}
Aim of the study

Water shortage in arid regions should be addressed strategically. We propose a framework for determining and prioritizing sustainable water management strategies based on Sustainable Development Goal 6.

Material and methods

In this research, the water resources management strategies in the Central Desert Basin of Iran were derived by using brainstorming technique and analysing Strengths, Weaknesses, Opportunities, and Threats (SWOT). Then, these strategies were ranked using the Analytic Hierarchy Process based on the sustainable development criteria.

Results and conclusions

As a result, 9 strategies were developed, and assessed based on the sustainable development criteria including four categories: economic, social, environmental, and technical. The result of assessing strategies showed that the strategy of "constructing a wastewater collection network and treatment facilities, and reusing wastewater in industry and agriculture" was ranked first, and the strategy of "transferring water from adjacent basins" was ranked last. The results of sensitivity analysis showed that the model is sensitive to all of the sustainable development criteria except the "feasibility" criterion. Additionally, the model is more sensitive to the criterion of the "socio-cultural acceptance and participation of stakeholders" compared to the other criteria. Generally, the high-ranked strategies are grouped as the continuous and improvement strategies whereas the invasive strategies are ranked last. These results reveal the willingness of the professionals to meet the challenges of water scarcity in the long run, and relying on the strengths of the region rather than solving the problem at once which causes damages to the environment and natural resources.
\end{abstract}

Keywords: Analytic Hierarchy Process, Central Desert of Iran, Strategic Management of Water Resources, Sustainable Development Goals, Strengths-Weaknesses-Opportunities-Threats (SWOT) analysis

\section{INTRODUCTION}

Iran is one of the most vulnerable countries in terms of water resources, and most of its parts are suffering from water shortage (World Resources Institute, 1998).
The average precipitation is about $252 \mathrm{~mm} /$ year, and 65 percent of the area is classified as arid and semi-arid regions with an average precipitation of less than 150 $\mathrm{mm} /$ year (Falsoleiman and Chakoshi, 2008). In these areas, the aquifers are the only water source for the

凶e-mail: banihabib@ut.ac.ir 
economic and social demands, which have been dramatically affected by extensive water withdrawal in the recent decades. The Central Desert of Iran has access to the energy transmission networks and has ecological diversity, natural resources, environmental and wildlife sources, as well as the ability to improve its cultivated areas and development capabilities consisting of several large and the central provinces. The imbalance between water supply and demand, the resource degradation, the interaction and competition between the different groups of water users have contributed to the essential need for a new water resource management planning. The plan should have a comprehensive and strategic vision based on sustainable development goals, not only to address the conflicts and disparities in the different sectors, but also to eliminate the risks for the future generations from point of view of the water supplies.

Some studies applied Strengths, Weaknesses, Opportunities and Threats (SWOT) analysis to find the strategies for the water resources planning, but without ranking the derived strategies. For example, Dummer et al. (2009) investigated the optimal management of water resources in the Lebanese River Basin using SWOT analysis. The results of the analysis suggest reducing demand and water consumption (Doummar, Massoud et al., 2009). In another research, Kalliorasa et al. (2010) studied water resources management applying SWOT analysis to an aquifer in the northern coast of Greece, which has been exposed to seawater (Kallioras, Pliakas et al., 2010). These studies focused on deriving strategies for water resources planning, but they did not rank the derived strategies.

Some studies were conducted to rank various water resources projects. Okada et al. (2008) used an AHP model to improve the irrigation project, in which a questionnaire was prepared to evaluate how irrigation professionals appraise an irrigation project (Okada et al., 2008). Biswas (2011) investigated the Integrated Watershed Management (IWM) alternatives in the mountainous areas of Bangladesh using Analytic Hierarchy Process (AHP) model [5]. Quaddus and Siddique (2011) conducted research using a decision conferencing approach for the assessment of water management alternatives in the agricultural sector. The result showed that the decision conferencing approach is useful in addressing the complexity of sus- tainable development plans. Aznarivand et al. (2014) carried out research in which a fuzzy analytic hierarchy process (FAHP) approach was applied to assess the environment and water management in the Urmia Lake Basin. In this study, the advantages of the combination of the FAHP technique with strength-weakness-opportunity-threat (SWOT) analysis for the assessment of sustainable development were discussed (Azarnivand, Hashemi-Madani et al., 2015). Furthermore, Banihabib et al. (2015) proposed a strategic plan, in which Strategic Sustainable Planning Framework (SSPF) was used, incorporating the SWOT analysis matrix, sustainable development criteria (SDC), and multi-criteria decision-making models (MCDMs), in order to suggest a strategy to prevent the water shrinkage of Lake Urmia. In this study, AHP, Simple Additive Weighting (SAW), and Technique for Order of Preference by Similarity to Ideal Solution (TOPSIS) methods were applied in order to rank the strategies, and the results were compared with the combination of SWOT and Quantitative Strategic Planning Matrix (SWOT-QSPM) (Banihabib, Azarnivand et al. 2015). In another study, Azrnivand et al. (2016) studied Lake Urmia in order to analyze sustainable watershed planning. This study focused on using the integration of TOPSIS and Quantitative Strategic Planning Matrix (QSPM) (Azarnivand and Banihabib, 2017). It was an attempt to apply MCDMs to ranking water resources projects such as irrigation, lake restoration, and the agricultural water management. These studies focused on deriving demand management for lake restoration, and agricultural water management using the MCDM. In contrast, in the present paper, we attempted to derive both the demand and the supply strategies and rank them in order to address sustainable development goals in arid regions.

The assessment of these studies demonstrates that employing the SWOT method is an appropriate technique to determine the strategies. However, it neither accurately prioritizes the strategies nor does it reflect the sustainable development goals in finding the best strategy. Therefore, addressing these deficiencies is of great concern, and the AHP method could be a proper solution to overcome this weakness. In fact, the combination of these two approaches not only provides the possibility to develop the strategies but it also ranks the strategies. This research emphasizes the need for 
the integration of SWOT and AHP with the view to developing and ranking sustainable water management strategies to address sustainable development goals in arid regions.

The two objectives in this research are:

- Developing a framework for determining and prioritizing sustainable water management strategies.

- Addressing water scarcity challenge based on Sustainable Development Goal 6 (SDG 6) and deriving a strategic plan for water resources management in the studied arid region.

\section{MATERIAL AND METHODS}

\section{Case study}

The Central Desert Basin, as one of the biggest arid regions in Iran, was selected as a case study to develop and rank the sustainable water management strategies to address the sustainable development goals. The Central Desert Basin has more than 227,000 square kilometers and more than $49.3 \%$ of this study area is located in the Semnan Province, $30.6 \%$ in the Kho- rasan Razavi Province, and 20.1\% in the Tehran, Isfahan North Khorasan and Yazd Provinces (see: Fig. 1). Most of the population in the area inhabits the north part of the basin. The total surface water is estimated at 64.89 million cubic meters. In addition, $98 \%$ of the water consumption is allocated to agriculture. The average annual rainfall is $83.8 \mathrm{~mm}$ with the highest rainfall in February and the lowest rainfall in September. The annual evaporation is about $23940.08 \mathrm{~mm}$, and the region has a dry climate according to the Domartan drought index. On average, $90.26 \%$ available water in the region is allocated to agriculture, $3.48 \%$ to drinking, $0.02 \%$ to health, $3.77 \%$ to urban water consumption, $2.13 \%$ to livestock sector and $0.33 \%$ to the remaining water users. 78.3 percent of the basin consists of land without vegetation, desert and poor pasture, and the remainder is comprised of: $0.04,0.03,1.85$ and 15.25 percent for arable lands, orchids, average pasture and poor pasture, respectively. The irrigated plants are wheat, barley, cotton, watermelon, alfalfa, melon, caraway, cantaloupe, sunflower, cumin, pomegranate, date, pistachio, grape, fig, onion, tomato, gar-

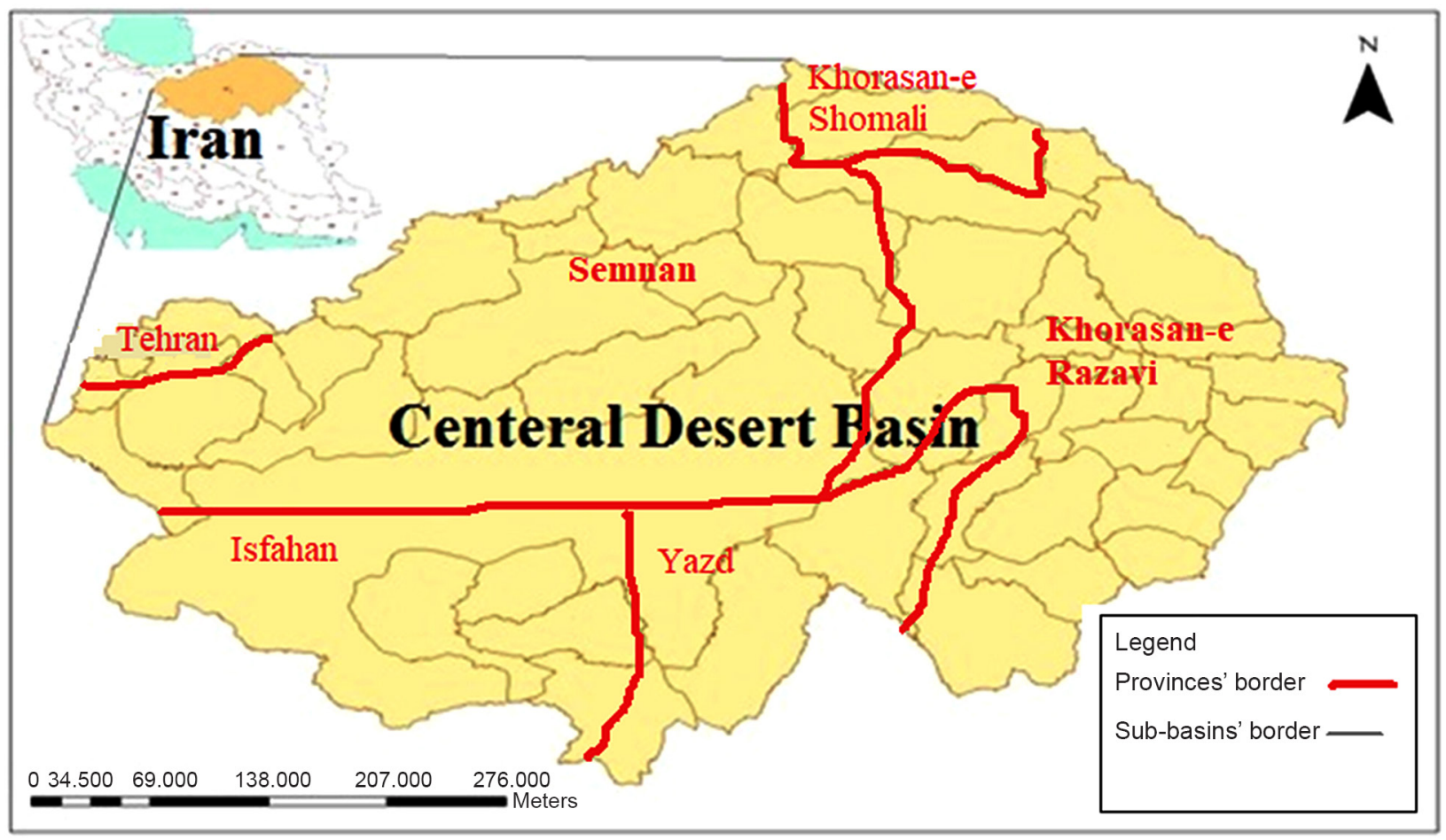

Fig. 1. Iran's Central Desert Basin 
lic, carrot, radish, turnip, and beetroot. There are also several sand, gravel, feldspar, industrial soils and the betonite mines in the study area.

The assessment of surface water resources in the Central Desert Basin shows that the total amount of precipitation is 33.20 Billion Cubic Meters (BCM), of which $22.76 \mathrm{BCM}$ falls in the mountainous parts of the basin, and 104.47 BCM falls in the plain part of the basin. Also, this basin has $2.69 \mathrm{BCM}$ surface runoff, in which $2.36 \mathrm{BCM}$ and $0.33 \mathrm{BCM}$ derive from the mountains and the plain of the basin, respectively. Twelve small reservoir dams with limited volume are used as surface water storage in the area. The average annual volume of these dams is 0.170 BCM. Furthermore, water withdrawal from groundwater resources is via 17080 wells, 4956 qanats, and 6632 springs. In total, the amount of discharge from groundwater resources in the Central Desert is estimated at about 6.84 BCM per year, $80 \%$ of which is discharged by wells. The balance of aquifer is $-0.97 \mathrm{BCM}$. Review of these data shows that the main water resource in the basin is groundwater, with considerable water shortage $(0.97 \mathrm{BCM})$. The relatively small volume of surface water shows that water engineering projects such as artificial groundwater recharging cannot be the main strategy to restore the aquifer, and that focus should be on water demand management.

Moreover, in the study area, water transmission efficiency is estimated between $50-60 \%$, water distribution efficiency between $50-60 \%$, farm efficiency 50 $-40 \%$ and finally efficiency for water agricultural plans is between $15-20 \%$, which demonstrates low agricultural water efficiency (Iran Water Resources Management Company, 2012). Additionally, global warming and climate change have their inevitable consequences for water resources which can limit water supply in the near future (Banihabib et al., 2016). Both low water use efficiency and global climate change impacts warn us to focus on strategies for increasing water use efficiency in the future.

Taking the above-mentioned data into consideration, it is obvious that the lack of rainfall, the negative balance in the aquifers, and the factors such as the high water use crops, the inadequate irrigation methods, the lack of the agricultural associations, and failure to enforce the water sector laws and the regulations are contributing to the water crisis in the studied area. To address these issues, it is vital to develop the appropriate strategies regarding the characteristics of the study area. The expert committee including water engineers, academic professionals, water resource and agricultural authorities discussed the above features of the region in the brainstorming meeting to develop water resources management strategies.

\section{Development of strategies}

brainstorming is a method of the group decision making, in which professionals state their innovative opinions and thoughts concerning the subject, led by a manager (Atai, 2010). The strengths, weaknesses, opportunities and threats of the water resources management in the area were discussed and analyzed using the brainstorming approach in the expert committee and summarized as follows:

The Strengths (S) of the study area:

S1. High literacy rate in the region $(77 \%)$

S2. High value of water in the desert culture

S3. Source of wastewater that can be recycled and used as the water resource

S4. Possibility of introducing the new methods of the water supply

S5. Rich agricultural land

S6. Possibility to invest in mining, such as a bentonite mine

S7. Rich sunlight for the development of solar energy

S8. Flat, cheap, and extensive land

The Opportunities $(\mathrm{O})$ of the study area:

O1. Possibility to import non-strategic agricultural products with high virtual water

O2. Tourist attractions for desert tourism and astronomy

O3. Existence of the several universities in the vicinity of the area, which carry out the research into advanced water resources strategies

O4. Having laws and regulations for water management

O5. Having a transit route from the several places with good road networks

O6. Public readiness to save water

O7. Possibility of industrial development due to its low impact on desert environment

O8. Possibility of trading the agricultural water 
O9. Existence of the water resources in the northern Alborz and the Western Zagros river basins and ability to transfer water from these basins

The Weaknesses (W) of the study area:

W1. Negative water balance in the basin

W2. Lack of water measurement stations available for both surface and groundwater

W3. Crop with high water consumption

W4. Inappropriate irrigation methods with low irrigation efficiency

W5. Reduction in population and migration from rural areas

W6. Weak monitoring over the enforcement of the laws.

W7. Improper disposal of wastewater and contamination of the water source

W8. Small average size of farms in the region

W9. Absence of agricultural Non-Governmental Organizations (NGOs)

W10. Lack of special agricultural extension centers for arid areas

The Threats $(\mathrm{T})$ of the study area:

T1. Lack of rainfall for agriculture (hot and dry climate)

T2. Lack of permanent rivers

T3. Moving sand dunes in the area

T4. Low share of farmers' income from the final price of the crops

Taking into account all the above-mentioned internal factors (strengths and weaknesses) and external factors (opportunities and threats) of the ecosystem in the study area, an expert meeting was held, and water management strategies were developed using SWOT analysis. The SWOT analysis puts emphasis on the identification of the most significant internal and external factors of a system, in order to determine the strategies, which could fully use its strengths and opportunities to overcome the weaknesses and prevent the threats. After identifying and evaluating the internal factors (strengths and weaknesses) and the external factors (opportunities and threats), possible invasive, conservative, competitive and defensive strategies can be derived from a crossing point of strengths and weaknesses with opportunities and threats, as shown in the SWOT matrix in Table 1. Using the intersection of this matrix, all water supply and the demand management strategies were formulated in the study area as follows:

Strategy 1: Importing virtual water (Str1)

Strategy 2: Reallocating water from agriculture to industry and services (Str2)

Strategy 3: Enhancing law enforcement and coordinating an integrated management for the basin (Str3)

Strategy 4: Creating a water market (Str4)

Strategy 5: Constructing a wastewater network and treatment facilities, and reusing wastewater in industry and agriculture (Str5)

Strategy 6: Determining the optimal crop pattern and growing industry in the region (Str6)

Strategy 7: Training and promoting urban and agricultural water management (Str7)

Strategy 8: Developing a new urban and agricultural water distribution system, and improving the existing systems (Str8)

Strategy 9: Transferring water from adjacent basins ( $\operatorname{Str} 9)$

The strategies described as importing virtual water (Str1), reallocating water from agriculture to industry and services (Str2), enhancing law enforcement and coordinating an integrated management for the basin (Str3), creating a water market (Str4), determining the optimal crop pattern and growing industry in the region (Str6), as well as training and promoting urban and agricultural water management (Str7) are conservative

Table 1. Deriving strategies using the SWOT matrix

\begin{tabular}{cccc}
\hline \multirow{2}{*}{$\begin{array}{c}\text { SWOT matrix } \\
\text { Strengths }(\mathrm{S})\end{array}$} & \multicolumn{2}{c}{ Internal factors } \\
\cline { 2 - 3 } External factors & Opportunities $(\mathrm{O})$ & Invasive strategies group (SO) & Conservative strategies group (WO) \\
\cline { 2 - 4 } & Threats (T) & Competitive strategies group (ST) & Defensive strategies group (WT) \\
\hline
\end{tabular}


strategies (WO). The strategy of transferring water from the adjacent basins (Str9) is an invasive strategy (SO) made up of S8, O9. The strategy of constructing a wastewater network and treatment facilities and reusing wastewater in industry and agriculture (Str5) is a competitive strategy (ST) consisting of (W8, O4, S3, T1). The strategy described as developing a new urban and agricultural water distribution system and improving the existing systems (Str8) is a competitive strategy (ST), merging (S2, S4) with (T1).

\section{Sustainable development criteria}

Azarnivand and Banihabib (2013) examined several international and national documents and proposed the sustainable development criteria for water resources, using the domestic and international studies as follows (Azarnivand and Banihabib, 2013):

C1. Economic criterion: considering the cost-effectiveness of the strategies (Pierini, 2005, Sa-nguanduan and Nititvattananon, 2011).

C2. Public acceptance and socio-cultural participation criterion: the acceptance of the strategy by stakeholders and their willingness to take part in the strategy's implementation (Pierini, 2005)

C3. Natural resources and environmental conservational criterion: how far each strategy protects natural resources and environmental balance (Garfî et al., 2011; Sa-nguanduan and Nititvattananon, 2011).

C4. Effectiveness criterion: The extent to which the particular strategy impacts water scarcity or conservation of the existing water resources in the basin (Pierini, 2005; De Carvalho et al., 2009).

C5. Feasibility criterion: the strategy of implementation regarding the technical, research and the implementation capabilities and the natural, financial and legal constraints (De Carvalho et al., 2009, Garfì et al., 2011)

C6. Flexibility criterion: The capacity of the strategy to respond to natural or imposed pressures i.e. the resilience to maintain the system in a short or long-term irregularities (Foxon et al., 2002, Pierini, 2005).

The UN 2030 Agenda for Sustainable Development provided a global framework for the achievement of better economic policies, more social justice, and appropriate public welfare for nations and counties around the world in 2015. Among these 17 goals is the Sustainable Development Goal (SDG) 6, which focuses on water and sanitation issues. The SDG 6 urges increasing access to clean drinking water and sanitation for all people. It takes into account other factors contributing to water scarcity, such as population and agricultural growth, urbanization, and climate change, in order to address water stress (Ortigara et al., 2018). In this study we address SDG 6 by introducing and applying sustainable development criteria for prioritizing sustainable water management strategies.

\section{Decision makers}

The Delphi method is a group decision-making process in which experts' opinions and judgments on an issue are collected using a questionnaire, in order to discover creative ideas. The basis of the Delphi approach is to perceive the experts' opinions as the best possible solution in each field regarding any judgment for the area, so the validity of the Delphi method depends not on the number of the participants but on their scientific validity. The participants of the Delphi study should count from 5 to 20 individuals, depending on the type of the issue (Atai, 2010). In this research, the questionnaire was developed, in which 22 water, environmental, and climate experts were surveyed to aid decision-making process applying the Delphi method.

\section{Multi-criteria decision-making model}

In the multi-criteria decision-making models, each alternative is evaluated using several criteria, and the best choice is made, determining the desired level of criteria, or by the pairwise comparison of the criteria and options. In these methods, the qualitative criteria are transformed quantitatively and the best alternative is selected by comparing all criteria (Atai, 2010). The implementation steps of the multi-criteria decision making model include identifying decision-making objectives and decision makers, identifying alternatives, defining criteria, calculating the criterion values for the alternatives and forming a decision matrix, normalizing the values of the criteria, weighting the criteria and the decision makers, ranking the alternatives, and conducting sensitivity analysis of the uncertain components of the model (Asgharpour, 2008). 
The analytic Hierarchy Process (AHP) method, invented by Saaty in 1980 , contains 4 steps in analytical thinking. The first step is to form a hierarchical structure to combine complex issues with decision indices and decision alternatives (see: Fig. 2). The second step is to prioritize the criteria in pairwise comparisons assigning the numerical points, to determine the relative preference of elements. According to Saaty (1977), the pairwise comparison demonstrates the importance of two elements (criteria /strategies) on a scale from 1 to 9 , where the value of 1 represents equal importance, and 9 represents absolute importance (the highest degree of superiority). The relative weight vector of the criteria can be determined using Equation (1) as follows:

$$
A . W=\lambda . W
$$

where $\mathbf{A}$ is the pairwise comparison matrix of criteria/ strategies, $\mathbf{W}$ is the weight vector, and $\lambda$ is the eigenvalue.

The third step consists of pairwise comparisons to assign numerical points in order to determine the preference of the strategy compared to the other strategies in addressing the criterion. Each pairwise comparison matrix of the strategies can be used to determine the weight vector by applying Equation (1). These vectors are columns in the performance matrix, $P\left[\mathrm{p}_{\mathrm{ij}}\right] . \mathrm{p}_{\mathrm{ij}}$ to show performance of strategy $i$ in admitting criterion $j$. The final Weight of a Strategy (FWS) can be determined by using Equation (2).

$$
F W S=\sum_{j=1}^{n} p_{i j} \cdot W_{j}
$$

The fourth step is to confirm the reliability of the pairwise comparison matrices. If the largest eigenvalue of the pairwise comparison matrix is $\lambda_{\max }$, the inconsistency index is estimated using Equation (3) (Saaty, 1980):

$$
\text { I.I. }=\frac{\lambda \max -n}{n-1}
$$

where $n$ is the dimension of matrix $A$. The inconsistency rate would be obtained by using Equation (4).

$$
I . R .=\frac{I . I .}{I . I . R}
$$

where I.I.R. is the random inconsistency rate extracted from Table 2. The maximum acceptable value for inconsistency rate is 0.1 . If the inconsistency rate is higher than this amount, the decision maker should be asked to reconsider their questionnaire.

Table 2. Random inconsistency rate of paired comparison matrices (Saaty,1980)

\begin{tabular}{ccccccccccc}
\hline $\mathrm{n}$ & 1 & 2 & 3 & 4 & 5 & 6 & 7 & 8 & 9 & 10 \\
\hline I.I.R. & 0 & 0 & 0.58 & 0.9 & 1.12 & 1.24 & 1.32 & 1.41 & 1.45 & 1.45
\end{tabular}

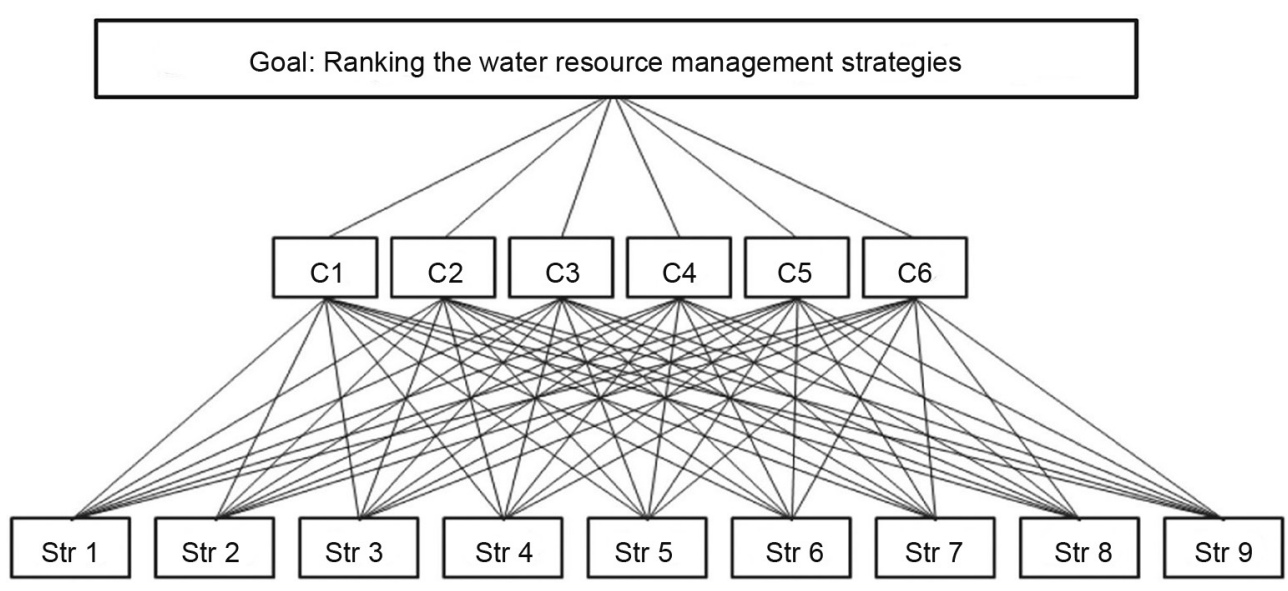

Fig. 2. The hierarchy process of a decision 


\section{RESULTS AND DISCUSSION}

\section{Strategies' ranks}

Using pairwise comparison matrix of the criteria and Equation (1), relative weights of the criteria are derived as shown in Table 3. The results point to "natural resources and environmental conservation criterion" as the most important criterion for evaluating strategies. It is higher than other criteria and ranked first by a significant margin (see: Table 3). It is followed by two other criteria, "effectiveness" and "economic" ranking second and third, respectively. As it is ranked first, the strategy of "Natural resources and environmental conservation" is fully justified due to the critical condition of the area in terms of water supply and the massive environmental impact of transferring water from one sector to another. Moreover, the criterion of "effectiveness" is ranked second, which is not unexpected, as it is more tangible than the other criteria in the public domain. Therefore, the most important criterion for experts is the criterion of "natural resources and environmental conservation". In addition, the lowest ranking among the water management strategies is the flexibility. As seen in Table 3, "the resilience to maintain the system in the view of short-term or long-term irregularities" was not as important as the other criteria according to the experts' opinions. Thus, they weighted it at about one-third of the most important criterion.

Table 3. Relative weight of sustainable development criteria

\begin{tabular}{clcc}
\hline Number & \multicolumn{1}{c}{ Criterion } & $\begin{array}{c}\text { Relative } \\
\text { weight }\end{array}$ & Rank \\
\hline C1 & Economic & 17.2 & 3 \\
\hline C2 & $\begin{array}{l}\text { Public acceptance and } \\
\text { socio-cultural participation }\end{array}$ & 13.7 & 5 \\
\hline C3 & $\begin{array}{l}\text { Conservation of natural } \\
\text { resources and the } \\
\text { environment }\end{array}$ & 26.7 & 1 \\
\hline C4 & Effectiveness & 17.6 & 2 \\
\hline C5 & Feasibility & 16.3 & 4 \\
\hline C6 & Flexibility & 8.5 & 6 \\
\hline
\end{tabular}

The results of the aggregate scores of the strategies and their ranking are shown in Table 4. By applying AHP, the strategy of constructing a wastewater network and treatment facilities, and reusing wastewater in industry and agriculture (Str5), as a continuous improvement strategy in the SWOT analysis, was ranked the highest. Moreover, strategies of "determining optimal crop pattern and growing industry in the region (Str6)" and "training and promoting urban and agricultural water management (Str7)", which also are the gradual and long-term improvement strategies ranked in the second place, while the strategy of "transferring water from adjacent basins", as the invasive strategy, ranked the last. These results illustrate the experts' willingness to address the long-term water scarcity and to rely on the basin strengths rather than a quickfix solution that could potentially damage the environment and natural resources, which is predictable from the experts' point of view concerning "natural resources and environmental conservation".

Table 4. Strategies ranking by the model

\begin{tabular}{|c|c|c|c|}
\hline Symbol & Strategy & $\begin{array}{l}\text { Final weight } \\
\text { of strategies } \\
\text { (FWS) }\end{array}$ & Rank \\
\hline Str1 & Importing virtual water & 0.113 & 4 \\
\hline Str2 & $\begin{array}{l}\text { Water reallocation from } \\
\text { agriculture to industry and } \\
\text { services }\end{array}$ & 0.081 & 6 \\
\hline Str3 & $\begin{array}{l}\text { Enhancing law enforcement } \\
\text { and introducing } \\
\text { a coordination of integrated } \\
\text { management for the basin }\end{array}$ & 0.11 & 5 \\
\hline Str4 & Creating a water market & 0.076 & 7 \\
\hline Str5 & $\begin{array}{l}\text { Constructing wastewater } \\
\text { network and treatment } \\
\text { facilities, and reusing } \\
\text { wastewater in industry and } \\
\text { agriculture }\end{array}$ & 0.146 & 1 \\
\hline Str6 & $\begin{array}{l}\text { Determining optimal crop } \\
\text { pattern and growing industry } \\
\text { in the region }\end{array}$ & 0.145 & 2 \\
\hline Str7 & $\begin{array}{l}\text { Training and promoting } \\
\text { urban and agricultural water } \\
\text { management }\end{array}$ & 0.145 & 2 \\
\hline Str8 & $\begin{array}{l}\text { Developing a new urban and } \\
\text { agricultural water distribution } \\
\text { system, and improving the } \\
\text { existing systems }\end{array}$ & 0.121 & 3 \\
\hline Str9 & $\begin{array}{l}\text { Transferring water from } \\
\text { adjacent basins }\end{array}$ & 0.062 & 8 \\
\hline
\end{tabular}


The results obtained from ranking water supply and water consumption management strategies in the basin showed that since the water resources limitation in the arid and semi-arid countries is highly problematic in the agricultural sector, the strategy of constructing a wastewater network and treatment facilities, and reusing wastewater in industry and agriculture (Str5) can play a prominent role in strategic water resources management in arid region. Therefore, the use of the unconventional water resources and wastewater systems in these regions is becoming increasingly important, and can be considered part of the strategy.

\section{Sensitivity Analysis of the Model}

The results obtained from the group opinion cannot be considered absolutely correct. Due to some uncertainty, inaccuracy, and ambiguity in the voters' minds, which leads to uncertainties in opinions, sensitivity analysis was carried out on the original criterion relative weights derived from the group opinion. This step allows the decision maker to have different ranks of the alternatives and to analyze the results of the changes through a slight shift in the relative weight of the criteria. In this study, to evaluate the sensitivity of the decision model, the criteria weights were altered $\pm 20 \%$ and the results were assessed (see: Table 5).

Most of the strategies were changed in the sensitivity analysis of the model, and in general it seems that the sensitivity of strategies ranking to the change in criteria is significant. As Table 6 illustrates, the strategy of "constructing a wastewater network and treatment facilities, and reusing wastewater in industry and agriculture" (Str5) is sensitive to economic, flexibility, effectiveness, public acceptance and socio-cultural participation criteria. Moreover, the strategy of "determining optimal crop pattern and growing industry in the region" (Str6) is sensitive to effectiveness, acceptance and socio-cultural participation of stakeholders, natural resources, and environmental conservation criteria. The strategy of "training and promoting urban and agricultural water management strategy" (Str7) is sensitive to all criteria except the feasibility criterion. These three strategies being ranked first are sensitive to economic, and public acceptance and socio-cultural participation criteria, therefore they significantly affect the selection of the best strategy since changes in the relative weight of criteria can lead to changes in the ranking the strategies. Other strategies such as "water reallocation from agriculture to industry and services" (Str1), "creating a water market" (Str4), "enhancing law enforcement and coordinating an integrated management" (Str3) and "transferring water from the adjacent basins" (Str9) are sensitive only to public acceptance and socio-cultural participation criterion. Furthermore, strategies, namely "importing virtual water" (Str1) and "developing new urban and agricultural water distribution system and improving the existing systems" (Str8) are not sensitive to any criterion. Therefore, the most sensitive criterion is

Table 5. Minimum, original and maximum relative weights for criteria

\begin{tabular}{clccc}
\hline Symbol & \multicolumn{1}{c}{ Criterion } & $\begin{array}{c}\text { Minimum tested } \\
\text { relative weight } \\
(20 \% \text { decreased value })\end{array}$ & $\begin{array}{c}\text { Original relative } \\
\text { weight }\end{array}$ & $\begin{array}{c}\text { Maximum tested relative } \\
\text { weight } \\
(20 \% \text { increased value })\end{array}$ \\
\hline $\mathrm{C} 1 \quad$ Economic & 13.8 & 17.2 & 20.6 \\
\hline $\mathrm{C} 2$ & $\begin{array}{l}\text { Public acceptance and socio-cultural } \\
\text { participation }\end{array}$ & 11.0 & 13.7 & 16.4 \\
\hline $\mathrm{C} 3$ & $\begin{array}{l}\text { Conservation of natural resources and } \\
\text { the environment }\end{array}$ & 21.4 & 26.7 & 21.1 \\
\hline $\mathrm{C} 4$ & Effectiveness & 14.1 & 17.6 & 19.6 \\
\hline $\mathrm{C} 5$ & Feasibility & 13.0 & 16.3 & 10.2 \\
\hline $\mathrm{C} 6$ & Flexibility & 6.8 & 8.5 & 2 \\
\hline
\end{tabular}


Table 6. Comparing strategies' ranks for original (initial) ranking, minimum (-) and maximum (+) tested relative weight of criteria

\begin{tabular}{ccccccccccc}
\hline $\begin{array}{c}\text { Strategy } \\
\text { No. }\end{array}$ & $\begin{array}{c}\text { Initial } \\
\text { ranking }\end{array}$ & C1- & C1 & C2- & C2+ & C3- & C4- & C4+ & C6- & C6+ \\
\hline Str1 & 5 & 5 & 5 & 5 & 5 & 5 & 5 & 5 & 5 & 5 \\
\hline Str2 & 7 & 7 & 7 & 7 & $6^{*}$ & 7 & 7 & 7 & 7 & 7 \\
\hline Str3 & 6 & 6 & 6 & 6 & $9 *$ & 6 & 6 & 6 & 6 & 6 \\
\hline Str4 & 8 & 8 & 8 & 8 & $7^{*}$ & 8 & 8 & 8 & 8 & 8 \\
\hline Str5 & 1 & 1 & $2^{*}$ & 1 & $2^{*}$ & 1 & $2^{*}$ & 1 & 1 & $2^{*}$ \\
\hline Str6 & 2 & $3^{*}$ & $1^{*}$ & 2 & $3^{*}$ & $1^{*}$ & $3^{*}$ & 2 & 2 & 2 \\
\hline Str7 & 2 & $1^{*}$ & $3^{*}$ & $3^{*}$ & $1^{*}$ & $1^{*}$ & $1^{*}$ & $3 *$ & $3^{*}$ & $1^{*}$ \\
\hline Str8 & 4 & 4 & 4 & 4 & 4 & 4 & 4 & 4 & 4 & 4 \\
\hline Str9 & 9 & 9 & 9 & 9 & $8^{*}$ & 9 & 9 & 9 & 9 & 9 \\
\hline
\end{tabular}

* Changed strategy ranks due to change in relative weight of the criteria

public acceptance and socio-cultural participation, in which changes can shift the strategies' ranking, reflecting the sensitivity of the experts on this criterion.

\section{CONCLUSIONS}

To sustainably manage water resources in the Central Desert Basin and to address the water scarcity challenge in the arid region basin, SWOT analysis and multi-criteria decision-making were combined to rank water resources management strategies based on sustainable development criteria. In this research, strengths, weaknesses, opportunities and threats were extracted for the study area by the brainstorming method. Nine main strategies were developed using SWOT analysis, and they were ranked based on sustainable development criteria using the AHP model. The results show that the continuous improvement strategies such as constructing a wastewater network and treatment facilities, and reusing wastewater in industry and agriculture (Str5), determining optimal crop pattern and growing industry in the region (Str6) and training and promoting urban and agricultural water management (Str7) were ranked 1th, 2nd and 3rd, respectively. Moreover, the invasive strategy of transferring water from the adjacent basins was ranked the last. These results indicate that there is a tendency for experts to meet the challenge of water scarcity in the long term by taking the basin strengths into account rather than instantly solving problem, which is likely to damage the environment and natural resources. Generally, the experts' tend more towards those strategies, which do not harm the environment. In addition, our study revealed that the issue of transferring water from the adjacent basin into the Central Desert Basin resulted from the strategy of "transferring water from adjacent basins" is not correct, and should be avoided, as this strategy does not admit the sustainable development criteria.

Even though this study shows that the strategy of transferring water from the adjacent basins is not a priority, the balance of aquifer shows considerable shortage, therefore some transfer of water from the adjacent basins may be required to cover water demand in industrial and urban water sectors. It should be noted that because of low water efficiency in agriculture sector, transferring water from the adjacent basins for agricultural use is not recommended at all.

Furthermore, the AHP approach could prioritize factors or criteria at each level of the hierarchy process using the eigenvalue calculation for pairwise comparisons. However, the interdependencies or inner dependencies among decision factors and their impact on each other could not be evaluated by this technique. Therefore, we recommend using the Analytic Network Process (ANP) model for further research as it takes into account the inner links among the strategies and between the criteria. Moreover, further research can be conducted to link SWOT with ANP model. 


\section{REFERENCES}

Asgharpour, M. J. (2008). Multiple Criteria Decision Making. Iran: University of Tehran press-Iran.

Atai, M. (2010). Group making decisions Iran, Shahrood University of Technology.

Azarnivand, A., Banihabib M. E. (2013). The Identification of Effective Factors of Strategic Implementation in Water Resources Management (Case Study: Lake Urmia Basin). Desert, 18(2), 177-183.

Azarnivand, A., Banihabib M. E. (2017). A multi-level strategic group decision making for understanding and analysis of sustainable watershed planning in response to environmental perplexities. Group Decision and Negotiation, 26(3), 629-648.

Azarnivand, A., Hashemi-Madani F. S., Banihabib M. E. (2015). Extended fuzzy analytic hierarchy process approach in water and environmental management (case study: Lake Urmia Basin, Iran). Environmental Earth Sciences, 73(1), 13-26.

Banihabib, M. E., Azarnivand, A., Peralta, R. C. (2015). A new framework for strategic planning to stabilize a shrinking lake. Lake and Reservoir Management, 31(1), 31-43.

Banihabib, M. E., Hasani K., Bavani, A.R.M., Asgari K. (2016). A framework for the assessment of reservoir operation adaptation to climate change in an arid region. International Journal of Global Warming, 9(3), 286-305.

De Carvalho, S., Carden, K.J. Armitage, N.P. (2009). Application of a sustainability index for integrated urban water management in Southern African cities: case study comparison-Maputo and Hermanus. Water Sa, 35(2).

Doummar, J., Massoud, M. A., Khoury R., Khawlie, M.R. (2009). Optimal water resources management: Case of lower Litani River, Lebanon. Water Resources Management, 23(11), 2343-2360.

Falsoleiman, M., Chakoshi, B. (2008). The role of optimum management of farming water consumption to in- crease the exploitation and stability of water resources of critical plains in arid areas of the country. Journal of Geography and Regional Development (Peer-reviewed), 9 .

Foxon, T. J., Mcilkenny G., Gilmour D., Oltean-Dumbrava C., Souter N., Ashley R., Butler D., Pearson, P., Jowitt, P., Moir, J. (2002). Sustainability criteria for decision support in the UK water industry. Journal of Environmental Planning and Management, 45(2), 285-301.

Garfî, M., Ferrer, L., Bonoli, A., Tondelli, S. (2011). Multicriteria analysis for improving strategic environmental assessment of water programmes. A case study in semi -arid region of Brazil. Journal of environmental management, 92(3), 665-675.

Kallioras, A., Pliakas, F.K., Diamantis, J., Kallergis, G. (2010). SWOT analysis in groundwater resources management of coastal aquifers: a case study from Greece. Water International, 35(4), 425-441.

Okada, H., Styles, S.W., Grismer, M.E. (2008). Application of the Analytic Hierarchy Process to irrigation project improvement: Part II. How professionals evaluate an irrigation project for its improvement. Agricultural Water Management, 95(3), 205-210.

Ortigara, A.R.C., Kay, M., Uhlenbrook, S. A. (2018). A review of the SDG 6 synthesis report 2018 from an education, training, and research perspective. Water 10(10), 1353.

Pierini, N. (2005). Sustainability indicators for urban water management.

Sa-nguanduan, N., Nititvattananon, V. (2011). Strategic decision making for urban water reuse application: A case from Thailand. Desalination, 268(1-3), 141-149.

Saaty, T. (1980). The Analytic Hierarchy Process Mcgraw Hill, New York. Agricultural Economics Review, 70.

World Resources Institute (1998). World Resources 199899. A Guide to the Global Environment, World Resources Institute.

\title{
PRIORYTETYZACJA STRATEGII ZRÓWNOWAŻONEJ GOSPODARKI WODNEJ W REGIONACH SUCHYCH I PÓŁSUCHYCH Z WYKORZYSTANIEM TECHNIKI AHP W POŁĄCZENIU Z ANALIZĄ SWOT W REALIZACJI CELÓW ZRÓWNOWAŻONEGO ROZWOJU
}

\author{
ABSTRAKT \\ Cel pracy \\ Problem niedoboru wody w regionach suchych wymaga podejścia strategicznego. W artykule zaproponowa- \\ no ramy definiowania priorytetów strategii zrównoważonej gospodarki wodnej w oparciu o cel 6 Zrównowa- \\ żonego Rozwoju ONZ.
}




\section{Materiały i metody}

W artykule przedstawiono strategie zarządzania zasobami wodnymi Wielkiej Pustyni Słonej w środkowym Iranie, które zostały opracowane przy użyciu techniki burzy mózgów i analizy SWOT (mocnych stron, słabych stron, szans i zagrożeń). Następnie opracowane strategie zostały uszeregowane za pomocą metody hierarchii analitycznej (AHP), w oparciu o kryteria zrównoważonego rozwoju.

\section{Wyniki i wnioski}

W rezultacie opracowano 9 strategii, które oceniono według kryteriów zrównoważonego rozwoju, w tym w czterech kategoriach: ekonomicznej, społecznej, środowiskowej i technicznej. Najwyżej oceniono strategię „,budowy kolektora i sieci oczyszczania ścieków oraz ponownego wykorzystania ścieków w przemyśle i rolnictwie”, zaś strategię ,transferu wody z innych regionów” oceniono najniżej. Wyniki analizy wrażliwości wykazały, że model jest wrażliwy na wszystkie kryteria zrównoważonego rozwoju z wyjątkiem kryterium „wykonalności”. Co więcej, model jest bardziej wrażliwy na kryterium ,akceptacji społeczno-kulturowej i udziału interesariuszy" w porównaniu z innymi kryteriami. Zasadniczo wysoko ocenione zostały strategie ciagłe i ulepszające, podczas gdy najniżej oceniono strategie inwazyjne. Wyniki badań ujawniają gotowość ekspertów i praktyków do sprostania wyzwaniom związanym z niedoborem wody w perspektywie długoterminowej i w oparciu o mocne strony regionu - w odróżnieniu od szukania szybkich, natychmiastowych rozwiązań, które jednak byłyby niekorzystne dla środowiska i zasobów naturalnych.

Słowa kluczowe: metoda hierarchii analitycznej, Wielka Pustynia Słona w Iranie, strategiczne zarządzanie zasobami wodnymi, cele zrównoważonego rozwoju, analiza SWOT (mocne strony-słabe strony-możliwości-zagrożenia) 


\section{PRIORITIZATION OF SUSTAINABLE WATER MANAGEMENT STRATEGIES IN ARID AND SEMI-ARID REGIONS USING SWOT COUPLED AHP TECHNIQUE IN ADDRESSING SDGS}

\section{SURVEY QUESTIONNAIRE FORM}

The Central Desert of Iran as one of the sub basins of the Central Iranian Plateau, with the code 4701 has an area of more than 57,000 square kilometers. We would like to express our gratitude for your sincere cooperation in expressing your constructive comments and filling this questionnaire, your name will be mentioned in the acknowledgement section of the research report.
It should be noted that this research is conducted in University of Tehran.

Table 1. The profile of respondents

\begin{tabular}{|c|c|c|c|}
\hline $\begin{array}{l}\text { The full name } \\
\text { of respondent }\end{array}$ & Affiliation & $\begin{array}{l}\text { Degree of } \\
\text { education }\end{array}$ & $\begin{array}{l}\text { Level of } \\
\text { familiarity with } \\
\text { the study area }\end{array}$ \\
\hline
\end{tabular}

Table 2. Scoring the sustainable development criteria

\begin{tabular}{llllll}
\hline \multicolumn{1}{c}{ Criteria } & \multicolumn{4}{c}{ Description scale } \\
\cline { 2 - 4 } & Very low & low & average & High & Very high \\
\hline Economic & & & \\
\hline Public acceptance and socio-cultural Participation & & & \\
\hline Conservation of natural resources and the environment & & \\
\hline Effectiveness & & & \\
\hline Feasibility & & & \\
\hline Flexibility
\end{tabular}

\section{Description on criteria:}

C1. Economic criterion: considering cost-effectiveness of the strategies.

C2. Public acceptance and socio-cultural participation criterion: the acceptance of the strategy by stockholders and their willingness to take part in the strategy implementation.

C3. Natural resources and environmental conservation criterion: the degree to which each strategy protects natural resources and environmental balance.
C4. Effectiveness criterion: The extent of that impact that the given strategy has on water scarcity or conservation of the existing water resources in the basin.

C5. Feasibility criterion: the strategy of implementation regarding the technical, research and the implementation capabilities and the natural, financial and legal constraints.

C6. Flexibility criterion: The capacity of the strategy to respond to natural or imposed pressures i.e. the resilience to maintain the system in view of short-term or long-term irregularities. 


\section{Pairwise comparison of criteria:}

In Table 4, if you consider both criteria to be equally important, mark only "equal importance" in the box and there is no need to fill in the next two columns. If you consider one of the criteria more important than the other one, first mark the "more important criterion" in its box, then score 1 to 9 in the last column of Table 4. Scale of the pairwise comparison of criteria is given in Table 3.
Table 3. Proposed scale for the pairwise comparison of the criteria

\begin{tabular}{ll}
\hline \multicolumn{1}{c}{ Degree of importance } & \multicolumn{1}{c}{ Description scale } \\
\hline 1 & Equal importance \\
\hline 3 & Relatively important \\
\hline 5 & More important \\
\hline 7 & Much more important \\
\hline 9 & Absolute importance \\
\hline $2,4,6$, and 8 & Intermediate values \\
\hline
\end{tabular}

Table 4. Pairwise comparison of the criteria to assess the goal of the study

\begin{tabular}{|c|c|c|c|}
\hline Criteria & Equal importance & More important criteria & Degree of importance \\
\hline \multicolumn{4}{|l|}{ Economic } \\
\hline \multicolumn{4}{|l|}{$\begin{array}{l}\text { Public acceptance and socio-cultural } \\
\text { participation }\end{array}$} \\
\hline Criteria & Equal importance & More important criteria & Degree of importance \\
\hline \multicolumn{4}{|l|}{ Economic } \\
\hline \multicolumn{4}{|l|}{$\begin{array}{l}\text { Natural resources and environmental } \\
\text { conservation }\end{array}$} \\
\hline Criteria & Equal importance & More important criteria & Degree of importance \\
\hline \multicolumn{4}{|l|}{ Economic } \\
\hline \multicolumn{4}{|l|}{ Effectiveness } \\
\hline Criteria & Equal importance & More important criteria & Degree of importance \\
\hline \multicolumn{4}{|l|}{ Economic } \\
\hline \multicolumn{4}{|l|}{ Feasibility } \\
\hline Criteria & Equal importance & More important criteria & Degree of importance \\
\hline \multicolumn{4}{|l|}{ Economic } \\
\hline \multicolumn{4}{|l|}{ Flexibility } \\
\hline Criteria & Equal importance & More important criteria & Degree of importance \\
\hline \multicolumn{4}{|l|}{$\begin{array}{l}\text { Public acceptance and socio-cultural } \\
\text { participation }\end{array}$} \\
\hline \multicolumn{4}{|l|}{$\begin{array}{l}\text { Natural resources and environmental } \\
\text { conservation }\end{array}$} \\
\hline Criteria & Equal importance & More important criteria & Degree of importance \\
\hline \multicolumn{4}{|l|}{$\begin{array}{l}\text { Public acceptance and socio-cultural } \\
\text { participation }\end{array}$} \\
\hline Effectiveness & & & \\
\hline
\end{tabular}


Table 4. cont.

\begin{tabular}{|c|c|c|c|}
\hline Criteria & Equal importance & More important criteria & Degree of importance \\
\hline \multicolumn{4}{|c|}{$\begin{array}{l}\text { Public acceptance and socio-cultural } \\
\text { participation }\end{array}$} \\
\hline \multicolumn{4}{|l|}{ Feasibility } \\
\hline Criteria & Equal importance & More important criteria & Degree of importance \\
\hline \multicolumn{4}{|c|}{$\begin{array}{l}\text { Public acceptance and socio-cultural } \\
\text { participation }\end{array}$} \\
\hline \multicolumn{4}{|l|}{ Flexibility } \\
\hline Criteria & Equal importance & More important criteria & Degree of importance \\
\hline \multicolumn{4}{|c|}{$\begin{array}{l}\text { Natural resources and environmental } \\
\text { conservation }\end{array}$} \\
\hline \multicolumn{4}{|l|}{ Effectiveness } \\
\hline Criteria & Equal importance & More important criteria & Degree of importance \\
\hline \multicolumn{4}{|c|}{$\begin{array}{l}\text { Natural resources and environmental } \\
\text { conservation }\end{array}$} \\
\hline \multicolumn{4}{|l|}{ Feasibility } \\
\hline Criteria & Equal importance & More important criteria & Degree of importance \\
\hline \multicolumn{4}{|c|}{$\begin{array}{l}\text { Natural resources and environmental } \\
\text { conservation }\end{array}$} \\
\hline \multicolumn{4}{|l|}{ Flexibility } \\
\hline Criteria & Equal importance & More important criteria & Degree of importance \\
\hline \multicolumn{4}{|l|}{ Effectiveness } \\
\hline \multicolumn{4}{|l|}{ Feasibility } \\
\hline Criteria & Equal importance & More important criteria & Degree of importance \\
\hline \multicolumn{4}{|l|}{ Effectiveness } \\
\hline \multicolumn{4}{|l|}{ Flexibility } \\
\hline Criteria & Equal importance & More important criteria & Degree of importance \\
\hline \multicolumn{4}{|l|}{ Feasibility } \\
\hline Flexibility & & & \\
\hline
\end{tabular}

\section{Determine the importance of each strategy}

To determine the importance of each strategy, simply mark one of the boxes in the description scale columns in tables 5-10. Please mark only one column in each row (for each strategy). 
Table 5. Scoring strategies according to the economic criterion

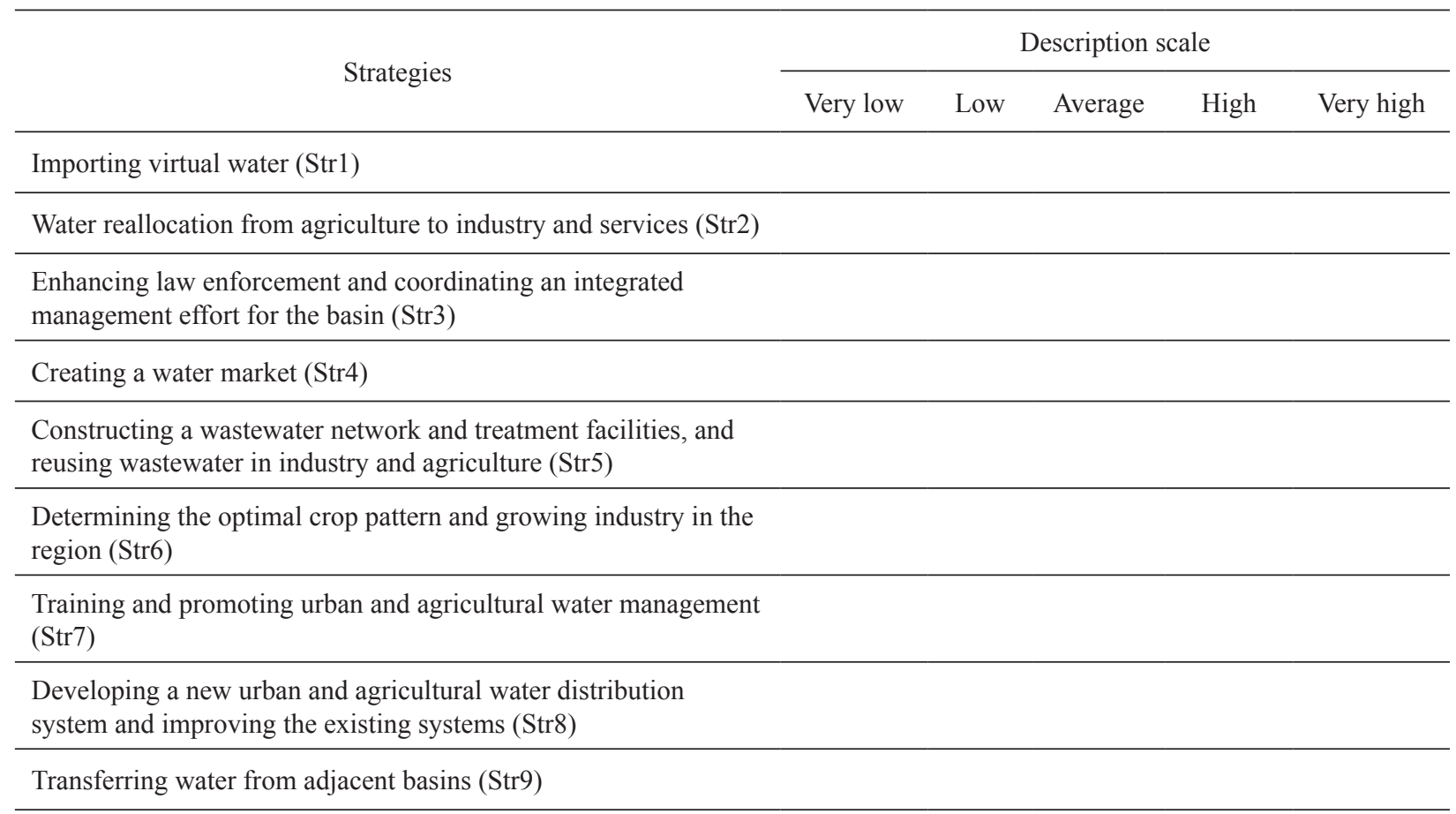

Table 6. Scoring strategies according to public acceptance and socio-cultural participation criterion

\begin{tabular}{|c|c|c|c|c|c|}
\hline \multirow{2}{*}{ Strategies } & \multicolumn{5}{|c|}{ Description scale } \\
\hline & Very low & Low & Average & High & Very high \\
\hline \multicolumn{6}{|l|}{ Importing virtual water (Str1) } \\
\hline \multicolumn{6}{|l|}{ Water reallocation from agriculture to industry and services (Str2) } \\
\hline \multicolumn{6}{|l|}{$\begin{array}{l}\text { Enhancing law enforcement and coordinating an integrated } \\
\text { management for the basin (Str3) }\end{array}$} \\
\hline \multicolumn{6}{|l|}{ Creating a water market (Str4) } \\
\hline \multicolumn{6}{|l|}{$\begin{array}{l}\text { Constructing a wastewater network and treatment facilities, and } \\
\text { reusing wastewater in industry and agriculture (Str5) }\end{array}$} \\
\hline \multicolumn{6}{|l|}{$\begin{array}{l}\text { Determining the optimal crop pattern and growing industry in the } \\
\text { region (Str6) }\end{array}$} \\
\hline \multicolumn{6}{|l|}{$\begin{array}{l}\text { Training and promoting urban and agricultural water management } \\
\text { (Str7) }\end{array}$} \\
\hline \multicolumn{6}{|l|}{$\begin{array}{l}\text { Developing a new urban and agricultural water distribution } \\
\text { system and improving the existing systems (Str8) }\end{array}$} \\
\hline Transferring water from adjacent basins (Str9) & & & & & \\
\hline
\end{tabular}


Table 7. Scoring strategies according to the natural resources and environmental conservation criterion

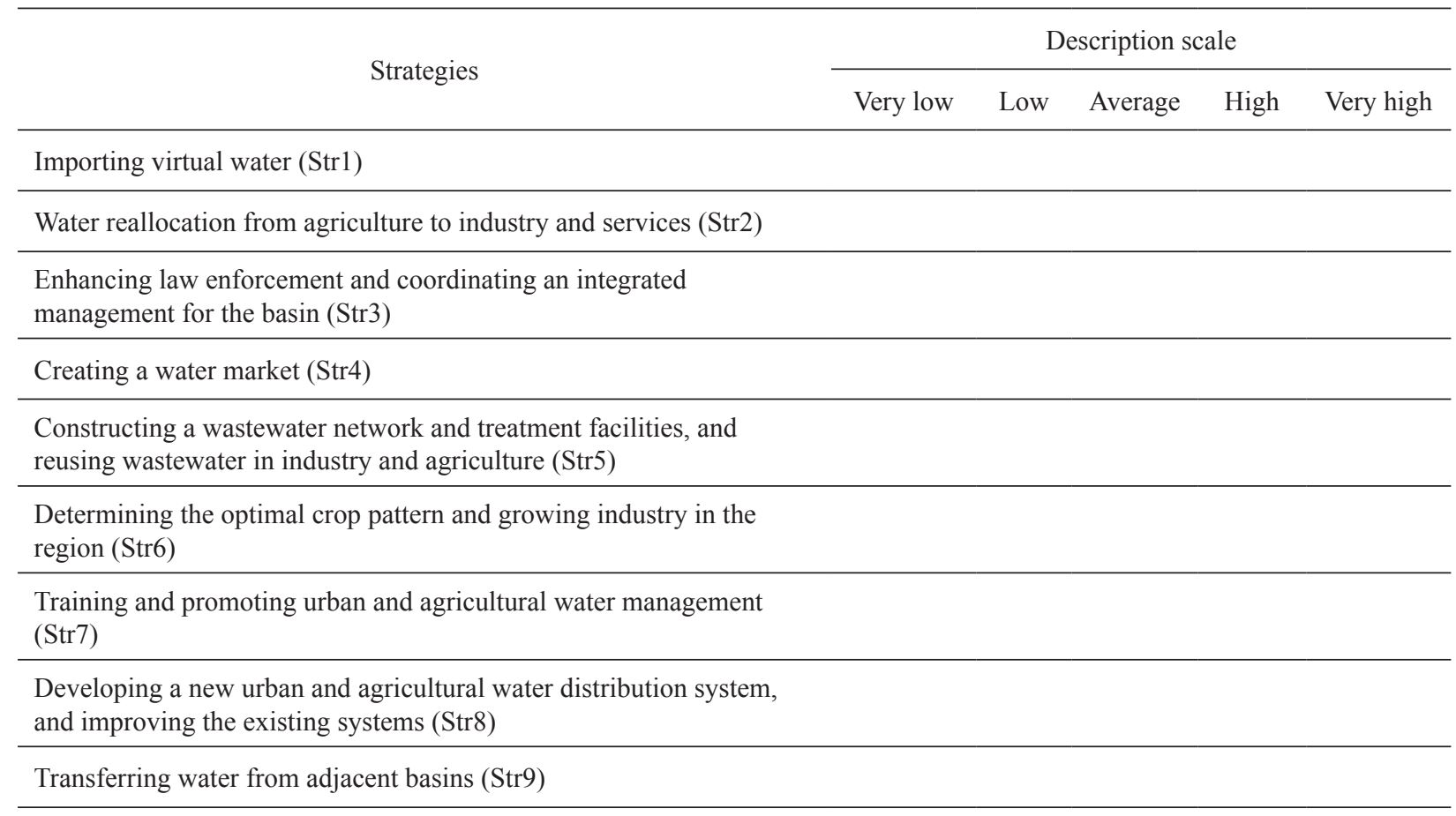

Table 8. Scoring strategies according to the effectiveness criterion

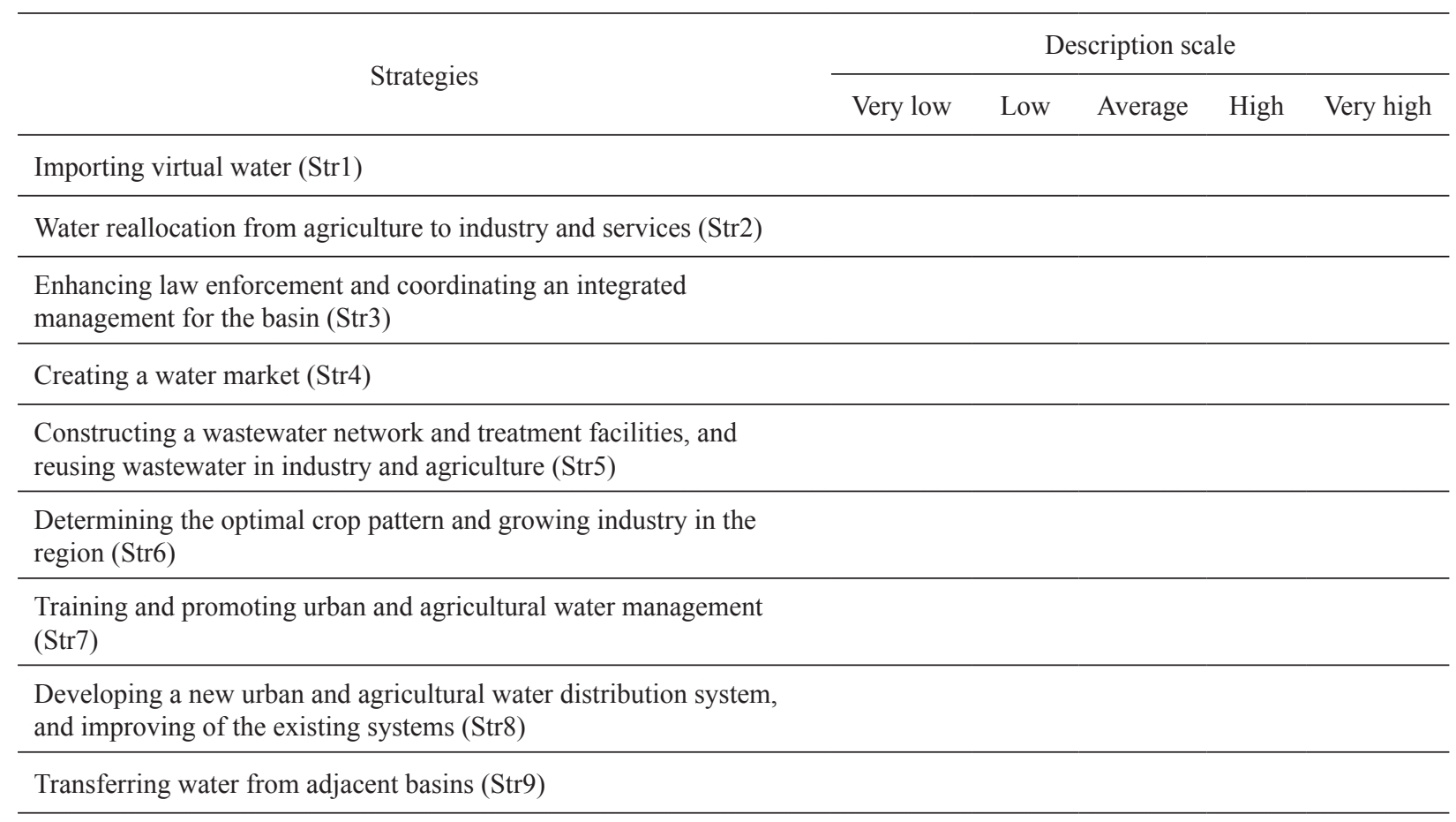


Table 9. Scoring strategies according to feasibility criterion

\begin{tabular}{lll}
\hline \multicolumn{1}{c}{ Strategies } & Description scale \\
\cline { 2 - 3 } & Very low & Low $\quad$ Average High $\quad$ Very high \\
\hline Importing virtual water (Str1) & \\
\hline Water reallocation from agriculture to industry and services (Str2) & \\
\hline $\begin{array}{l}\text { Enhancing law enforcement and coordinating an integrated } \\
\text { management for the basin (Str3) }\end{array}$ \\
\hline Creating a water market (Str4) \\
\hline $\begin{array}{l}\text { Constructing wastewater network and treatment facilities, and reusing } \\
\text { wastewater in industry and agriculture (Str5) }\end{array}$ \\
\hline $\begin{array}{l}\text { Determining the optimal crop pattern and growing industry in the } \\
\text { region (Str6) }\end{array}$ \\
\hline $\begin{array}{l}\text { Training and promoting urban and agricultural water management } \\
\text { (Str7) }\end{array}$ \\
\hline $\begin{array}{l}\text { Developing a new urban and agricultural water distribution system, } \\
\text { and improving the existing systems (Str8) }\end{array}$ \\
\hline Transferring water from adjacent basins (Str9) \\
\hline
\end{tabular}

Table 10. Scoring strategies according to the flexibility criterion

\begin{tabular}{lll}
\hline \multicolumn{1}{c}{ Strategies } & Description scale \\
\cline { 2 - 3 } Importing virtual water (Str1) & Very low & Low $\quad$ Average High $\quad$ Very high \\
\hline Water reallocation from agriculture to industry and services (Str2) & \\
\hline Enhancing law enforcement and coordinating an integrated \\
management for the basin (Str3) \\
\hline Creating a water market (Str4) \\
\hline $\begin{array}{l}\text { Constructing a wastewater network and treatment facilities, and } \\
\text { reusing wastewater in industry and agriculture (Str5) }\end{array}$ \\
\hline $\begin{array}{l}\text { Determining the optimal crop pattern and growing industry in the } \\
\text { region (Str6) }\end{array}$ \\
\hline $\begin{array}{l}\text { Training and promoting urban and agricultural water management } \\
\text { (Str7) }\end{array}$ \\
\hline $\begin{array}{l}\text { Developing a new urban and agricultural water distribution system, } \\
\text { and improvement of the existing systems (Str8) }\end{array}$ \\
\hline \begin{tabular}{l} 
Transferring water from adjacent basins (Str9) \\
\hline
\end{tabular}
\end{tabular}

